\title{
The intercultural crafting of real Aboriginal country and manhood in Central Australia
}

\author{
Åse Ottosson \\ Australian National University
}

This article explores country music as an important means for Aboriginal men in Central Australia to articulate contemporary forms of manhood and indigeneity. These desert men perceive their own music scene as a last stronghold for real country music. The article demonstrates how such notions of real involve the ongoing intercultural mediation of global and local male aesthetic styles and manhood ideals. In making and performing their country music, desert men continue to draw on enduring ancestral regimes for male demeanour that resonate with global country music imagery and practice, as well as with prominent nonIndigenous models of manhood in the regional settler history.

\section{INTRODUCTION}

Over the last eighty years, country music has come to play an immensely important private and public role in Australian indigenous lifeworlds, as music scholars and journalists have noted (such as Breen 1989; Dunbar-Hall \& Gibson 2004; Walker 2000). It is also a known phenomenon among Indigenous peoples in other settler societies (see for example, Diamond 2001; Samuels 2004). Despite its ever-presence in day-to-day Australian Indigenous settings, country music, and indeed popular music more generally, has rarely attracted anthropologists' attention as a socially and culturally generative practice. And while popular music scholars have paid attention to country music as a distinctive and meaningful Aboriginal practice, this literature has not generally attended to the inherently intercultural shaping of Aboriginal country music as embodied experience and expressive social practice.

In Central Australia, Aboriginal desert people have enthusiastically adopted and reworked certain country music styles into their own social worlds, memories and languages for more than half a century. Desert musicians frequently refer to these regional Aboriginal styles and music practices as real country. In this article, I take such local notions of real as a mediating point for exploring country music as socially productive in the intercultural crafting of contemporary Aboriginal and

The content of this article has not been published or submitted for publication elsewhere. It is the original work of the author and has undergone the appropriate consultations with informants according to ethical guidelines and cultural protocols. 
male selves in the Australian deserts. Conceptualising the social realm of Aboriginal country music making as intercultural mediation, I take into account how this realm 'connects and translates disparate worlds, people, imaginations, values, and ideas whether in its symbolic, social or technological form' (Meintjes 2003: 8). That is, country music making is here framed analytically as a process that connects the practicalities of an ongoing history of everyday life and interactions with more abstract levels of experience, such as memory, senses of emplacement and displacement, ideas of race and gender, and 'models of self- and personhood, poetics, theories of emotion, and structures of feeling' (Fox 2004: 34).

Aligning with thoughts of music practice as socially transformative in intercultural and transnational interplay (e.g. Gilroy 1993; Born \& Hesmondhalgh 2000; Radano \& Bohlman 2000; Wade 2000), the article more specifically addresses how gendered and Indigenous forms of identifying always emerge in relational dynamics. This means viewing the world of one person or group as always implicating the world of others, and questioning notions of socio-cultural identification as something pre-existing social relations (Jackson 1998). Drawing on long-term ethnographic research of everyday life and music making in Aboriginal settings, the discussion is also framed by recognition of all social practice, including real country playing, as involved in ongoing interactional histories of inequality and stratification.

\section{REAL PLAYING}

The sound of wailing rock guitar solos over thumping bass and drum beats reverberates through the recording studio downstairs at the Central Australian Aboriginal Media Association (CAAMA) in Alice Springs. What began with one of the Aboriginal sound engineers picking out a groovy bass guitar riff to test a loudspeaker rapidly developed into this increasingly loud jam session when other Aboriginal men who happened to be around grabbed drums sticks and guitars and joined in. I have retreated to the control room where I can control the volume on the sound-desk while watching the impromptu performance through the studio window. Two local Aboriginal country musicians who are studio regulars join me. They soon shake their heads, commenting that this was a kind of music they played when they were 'angry youngfellas'. They proceed to imitate two guitar-trashing, head-banging figures. 'Anyone can play that kind of music!' they chuckle. Country music, on the other hand, they want to convince me, requires more demanding, fine-tuned skills and maturity, in order to create many different and nuanced moods. They show me how with composed and calm gestures, their fingers moving gently over imaginary guitar strings. I point out that many famous country musicians also show off in rather elaborate stage gymnastics. This is met with dismissive gestures. 'Those mob is not real country', one of them concludes.

The rock-playing men out in the studio in fact behave nothing like the headbanging figures that the country musicians exaggerate. One of the first things a 
musically inclined researcher notices in the Australian desert region is how local Aboriginal musicians have not adopted many of the physically overt gestures of global rock or country performance conventions. While the men in the studio certainly churn out wildly thumping and loud rock music, their physical movements are minimal. The only evidence of their emotional involvement is an exchange of wide, satisfied grins. The country musicians still use the gestures of global stereotypes of showy and self-aggrandising rock performance styles and male figures in order to demonstrate the contrasting Aboriginal masculine models they associate with the two musical genres. That is, they wish to present country music making, with its more composed instrumental and vocal styles, as being on a higher level in a social and moral hierarchy of male respect, which is intimately connected to their understanding of real country and men as more complex and sincere. In order to pin down what exactly this real quality involves, we need to know the place and regional history in which these country music practices have become intimately entangled with particular ways of being Aboriginal men.

\section{THE COUNTRY}

Central Australia is a vast, sparsely populated desert region with one major town, Alice Springs (pop. 27 800). The region is occupied by enormous cattle stations, a few mining and petroleum operations and a handful of tourist resorts, the most famous located at Uluru (Ayers Rock), southwest of Alice Springs. About twentyfive per cent of the population in Central Australia identify as Indigenous, compared with just over two per cent nationally. Half of the land in the Central region has now been handed back to its traditional Aboriginal owners. These homelands are dotted with small, remote Aboriginal settlements where many people continue to organise their life based on customary principles associated with particular tracts of ancestral land and languages. ${ }^{1}$ While a pan-Australian Aboriginal/Indigenous/First People identity is now commonly adopted for political and other purposes, most desert people continue to identify with distinct localised orders affiliated with identifiable ancestral country and sites. More than twenty different Aboriginal languages and dialects are still spoken across the region (IAD 2002) and most of the male musicians from remote communities are ritually initiated men who take part in ceremonial life to various degrees. Musicians who grew up and live around Alice Springs, and especially those from mixed Aboriginal/non-Aboriginal families, may speak English only and may not be initiated men, but most of them know what ancestral country they belong to and how they are positioned in kin groupings.

Colonial incorporation and non-Aboriginal settlement of Central Australia began in the 1860s and proceeded in a slow and uneven process with the arrival of exploring parties, missionaries, cameleers, pastoralists, traders, miners, road workers, railway builders, rural workers and public servants from a number of different European and Asian backgrounds (Donovan 1988). In some places, local Aborigines 
and settlers became embroiled in chains of retaliatory violence when the locals resisted the invasion of their hunting grounds, waters, ancestral sites and women. In other places, Aboriginal people had less violent experiences and bonds of interdependence (although never on equal terms) developed between Aborigines and settlers. Everywhere, a large number of Aboriginal people died from introduced diseases, and their movements and lives were increasingly restricted by racist and dehumanising government policies (Austin 1992, 1997).

By WWII, most Aboriginal people worked and camped on cattle and sheep properties, in Christian missions, or on the fringes of white settlements. Following large scale rationalisation of the rural industries and the introduction of equal wages for the previously unpaid or underpaid Aboriginal rural workforce in the mid- to late 1960s, many Aboriginal workers were pushed out of the industry and had to leave the hinterland with their families. With few other work opportunities open to them, many became dependent on welfare, which saw them further marginalised from mainstream economy and society in Aboriginal missions, government settlements and on the outskirts of white towns (Berndt \& Berndt 1987). In the past four decades, considerable amounts of public funding have been invested in social programs and infrastructure under policies of Aboriginal self-determination and self-management, and this has been coupled with the recognition and protection of Indigenous rights through legislation in areas such as land rights. Today, Aboriginal agencies and organisations are major stakeholders in the Central Australian economy, while a situation of welfare dependency, unemployment and associated social problems is well entrenched for large segments of the Aboriginal population.

\section{ABORIGINAL COUNTRY}

Music was always an important part of the intercultural history of Central Australia, where Aboriginal and non-Aboriginal people had constant dealings with each other while maintaining voluntary as well as enforced distinctive social and cultural domains. The newcomers brought instruments, sounds and styles of singing and playing from many different musical traditions and places of origins. While local Aboriginal groups have adopted and internalised aspects of exogenous norms, values and practices within their own belief systems and everyday lives, Christianity and the pastoral industry have had a particularly important and still powerful influence for how Aboriginal people identify, dress and organise aspects of their everyday lives. Church music and country music are also the most widespread and long lasting European music forms in the region.

Christian hymns were first introduced by German Lutheran missionaries in the late nineteenth century (Hill 2002; : part I, ch. 2 and 3). Over time, these styles of music have been reworked into an Aboriginal genre of 'desert gospel', which is different from more well-known African-American funky and physically high-spirited gospel. In the merging of European Lutheran and local Aboriginal music forms and norms for appropriate bodily expressions, desert gospel is instead characterised by 
emotionally sparse singing styles and highly composed bodily expression (this has also been noticed, for instance, in the Hawai'ian setting, see Stillman 1996). This physically minimalist style, as noted in the studio scene, is also a prominent feature of Aboriginal desert country, rock and reggae performance conventions.

The association between gospel and country music elsewhere in the world is well established, the most famous example being the legendary Carter family in the United States in the 1920s. In Central Australia, country-gospel bands have been a mainstay of everyday Aboriginal community life since the 1950s, despite some early misgivings among missionaries who perceived country music as the work of the devil. When country music was introduced to the Hermannsburg mission during the late 1940s, for instance, it was banned by the Lutherans. Local Aboriginal country musicians had to practise this music in secret. Foremost among them was Arrernte-Waramungu man Gus Williams, who remained a formidable force in the Central Australian Aboriginal country music scene until he passed away recently. Gus told me how he and a group of Aboriginal country players from the mission took their music to nearby Palm Valley, an early tourist destination, where they found more appreciative audiences. By the early 1960s, the Lutherans had come to accept that country was here to stay, and it became an integrated feature of church music in the mission.

American hillbilly, cowboy song music and Australian bush balladry had already been introduced in the late 1920s by travelling white show men, such as the legendary New Zealand-born Tex Morton and Australian Buddy Williams. These forms of music were also a mainstay of touring country variety or rodeo shows that became highly popular in rural and remote Australia from the 1940s (Whiteoak 2003). Aboriginal audiences have, in fact, turned out to be the most loyal supporters of some white touring country artists such as Australian Slim Dusty over their lifelong careers, and have kept these artists afloat when white fans have turned to other musical styles (Dusty \& McKean 1996; Fitzgerald \& Hayward 2003).

From the 1950s, Hollywood western movies with singing cowboys further contributed to the hillbilly repertoire and related male imagery. The instrumental guitar music of these films is still widely popular in the regional Aboriginal music scene. Even more common is the 1950s and 1960s honky-tonk style country. More or less every Aboriginal person in the region has grown up with uncles strumming away on beat-up acoustic guitars, singing tunes of Hank Williams, Jimmie Rodgers, Charlie Pride and Merle Haggard, as well as Australian country legends such as Slim Dusty, Buddy Williams and Tex Morton. Mothers and aunties also knew their Loretta Lynn, Patsy Cline and Peggy Lee songs.

As these styles of country music have been heard, played and learnt as part of local all-Aboriginal forms of sociality for generations, many Aboriginal people do not think of them as 'introduced' music. Typically, when I documented the types of introduced music Aboriginal musicians heard when growing up, most of them took country music so much for granted that they did not mention it. When I asked specifically about country music, they often replied with statements like 'but that's blackfella music! It's always been there!' ${ }^{2}$ Country is thus essentially thought of as a 
'traditional' Aboriginal folk music, although in a separate register from that of their all-important ancestral and ritual music traditions. A further indication of this is how, when asked what particular country artists and styles the men heard when young, they do not necessarily mention the original white artists. They rarely use 'honky-tonk', 'hillbilly' or other common genre terms, either. Instead, they would sing or play a fragment immediately recognisable as a marker or theme of a specific style or era of country. They would then mention 'oldfella' Aboriginal musicians who introduced and reworked these styles in local Aboriginal settings. Some of the most respected and still influential of those country music 'elders' are Herbie Laughton, Gus Williams, Trevor Adamson, Isaac Yamma, Irwin Inkamala, Pantju 'Punch' Thompson and Bill Wellington. ${ }^{3}$

Today, most remote communities have country and country-gospel bands that play distinctive localised styles. The song lists of the many Aboriginal rock and reggae band formations in the region include country songs, too, as well as songs that fuse gospel, country, rock and reggae features. While this rich country music scene, like any musical culture, is thus highly diverse and always evolving, local Aboriginal musicians still commonly describe it with the one collective and distinguishing term: it is real country.

\section{REAL COUNTRY AND MEN}

When I arrive at the bi-weekly country music dance in Alice Springs, the room is packed with Aboriginal men, women, teenagers and children. ${ }^{4}$ The dance floor is taken up by women in colourful t-shirts and loose, below-the-knee-length skirts or sleeveless dresses. Men appear in the common male town gear-jeans, collared sport shirts and sports shoes-or in cowboy gear, including well-worn Akubras (Australian style cowboy felt hats), belts featuring large buckles, snap-button shirts, and dusty or polished cowboy boots. Older people and mothers with children sit at tables, smoking and drinking beers and soft drinks. Teenagers are involved in their own games at the back of the room. Kids, some barely yet walking, are making moves to the music up front, drawing wide smiles from the musicians on the slightly raised stage. As usual, Aboriginal country legends Gus Williams and Herbie Laughton are taking up two chairs at the side of the stage, monitoring the proceedings.

Dressed like other men in the room, the musicians on stage stand rather motionless as they serve up finger-picking guitar solos and swinging chord combinations that make the dancers go wild and happy. When a small boy falls on his padded back, one of the guitarists calmly walks over and lifts him up. He gestures for an older girl to come and look after the boy before he steps back up on stage and continues to play. After ending a Hank Williams tune with the characteristic twang, the musicians step down on the dance floor and become part of the crowds. Other men and a young female singer take their place. They start up a country song in the local Arrernte language. The shift on stage is barely noticed and people 
continue to dance, catch up with relatives and friends, play with babies, or just sit with closed eyes and hum along with the familiar tune.

Just like this country dance, most local Aboriginal country music events in Central Australia lack any sense of a staged 'concert' or 'performance'. It is more like entering an Aboriginal backyard or extended family gathering. At times, there are brawls and fights, also like in an Aboriginal backyard where people gather to drink and enjoy music. But mainly, it is a casual social event where Aboriginal men, and occasionally women singers, take the opportunity to perform their own and other's country songs together as well as in competition with other musicians.

So what is real about the country music at these events? Putting the question to a number of Aboriginal music makers in the region, they usually define this quality by listing what it is not. It is not 'American copy-cat' or 'Nashville', which they dismiss as insincere, plastic and standardised like commercial pop. They lament the fact that mainstream (i.e. whitefella and much urban Aboriginal) Australian country has degenerated into such 'American' directions, and proudly declare the Aboriginal desert music scene as a last stronghold for real country.

The local meanings these Aboriginal musicians attach to real versus 'American' country resonate with aspects of the globally widespread labels of 'hard-core' and 'soft-shell' country styles. The hard-core country sound, performance styles, dress codes and lyrical themes are usually associated with 'looking, talking, and acting like one of the audience and not like a professional entertainer with a fine singing voice, fashionable clothes, and the professional stage manner of a soft-shell entertainer' (Beal \& Peterson 2001: 236). In contrast to notions of commercial, inauthentic, insincere, slick and formulaic soft-shell country, the hard-core end of country is also generally associated with notions of 'home made, traditional, authentic, sincere, honest, from the heart' (Akenson 2003: 191).

These hard-core features reappear in most Aboriginal desert country events. Here, too, the blackfella musicians win recognition and respect from peers and audiences by appearing unpretentious and blending in with others in the way they dress or behave on stage. Importantly, such expressive features resonate with some enduring and highly valued adult male characteristics and ways of sustaining relatedness in Aboriginal desert societies. Generosity and unselfishness are often described in the literature as primary virtues in gaining respect as an autonomous, mature man in these societies (as described, for instance, by Liberman 1985; Meggitt 1962; Tonkinson 1974). This is associated with a show of 'general restraint and unassertiveness of individuals over their comrades' (Myers 1986: 103) and not putting oneself forward or appearing self-important. Regional Aboriginal norms for respected male demeanour thus correspond with the low-key, unassuming artistic imagery in real or hard-core country.

As demonstrated on stage in the described country dance, and by the country musicians' comments about the rock session in the CAAMA studio, aspects of the real quality of country and men are also defined by playing styles. This becomes clearer if contrasted with other stylistic conventions, especially those of the rock music genre. 


\section{PLAYING REAL}

In country music more generally, instrumentalists' main role is basically to submerge their contribution to the melody and to stay attentive to, enhance, and counterpoint the lead vocalist's expressions (for rich ethnographic description and discussion of country music practices and sensibilities, see Fox 2004). If instrumentalists do this too busily or too loudly they may be seen as incompetent, no matter how technically skilled and ingenious they might be. Musicians schooled in rock music expressions are, in contrast, valued for a narcissistic virtuosity on their particular instrument. They are expected to grab any space to show off in protracted solo playing, independent of the vocal melody. At times, vocalists also launch into a call and response game, often with thrusting and sexual gestures, with a lead guitar or drum solo, in effect directing the attention to individual instrumentalists' work. As the regional Aboriginal music scene of Central Australia demonstrates, though, such strong musical and often masculinist gestures are not necessarily executed with large physical gestures.

When put to work in Aboriginal socio-musical traditions in Central Australia, these differences in playing rock and country music become entangled with norms and values regarding adult Aboriginal male behaviour. We saw this in the gestures of the country musicians in the studio when they contrasted an uncontrolled youngfella rock playing figure with the playing of sincere, more adult, real country men in gentle and delicately controlled manners. The musicians on stage at the country dance likewise played in a gently attentive and casual manner, not drawing attention to their own person, while appearing as responsible men (who, for instance, attend to a child who falls over). The non-assertive way of playing real and respected country music with selfless attention to other band members thus resonates with Aboriginal norms for gaining respect as mature men, who ideally appear generous and unselfish and downplay their own persona in public. In contrast, it is expected that youngfellas will behave in more selfish, self-amplifying and irresponsible ways, having not yet mastered the skills of more knowledgeable and dignified men (e.g. Myers 1986: 238ff). Although the biological age of rock and country musicians may not differ, these generational ideals are still important for making evaluative distinctions between music-related masculine styles where the imagery of real country musicians portrays them as more complex and mature men. Western country music male imagery and playing conventions are in this way layered with Aboriginal norms for how adult men ideally behave and present themselves.

Distinctions between Aboriginal country and rock male imagery are also associated with the historical development of the two genres in the region. As outlined earlier, country music styles have been transferred in all-Aboriginal settings for several generations and have come to form a continuing expressive core of Aboriginal desert sociality. Country can thus be said to constitute a sonic 'oldfella' of regional musical styles. It is also literally embodied in the many older Aboriginal country 
musicians across the region. As such, country music has acquired a kind of respect that is related to the higher authority and respect attributed to older, (ideally) more mature, responsible and wiser men in regional Aboriginal social regimes. More recent socio-musical traditions have yet to earn such a deep male and social status. Some middle-aged rock musicians are certainly accorded a high degree of respect, too, but it tends to be earned more on an individual basis, for a man's personal skills or selfless contributions to his community, for instance. In contrast, country musicians often command a certain degree of respect simply by associating themselves with the long established social and masculine history of this Aboriginal genre, and by embodying the associated sincere and real maleness in the playing and performance of country music.

Another indication of this connection is that men playing rock and reggae in desert communities often turn to playing country and country-gospel music as they grow older. This coincides with the increased social and ritual responsibilities and male status that comes with maturing age in local Aboriginal regimes. It resonates, too, with aspects of ideal Christian models of adult masculinity which emphasise male responsibility for the protection and leadership of families and communities. A man's increased commitment to making country (and country-gospel) music as he grows older may thus be understood as a private and public expression and affirmation of a respected model of mature manhood in which customary and Christian values are co-implicated. Christian notions of ideal family relations are also played out in the desert country scene, as explored in the following section.

\section{REAL COUNTRY FAMILY AND MORALITY}

Aboriginal people have lived and worked in Christian missions and disciplinary regimes from the early days of European settlement in the region. Many older and middle-aged Aboriginal men I have worked with, and some younger men, identify strongly with the reverent and non-extroverted adult male demeanour of the Christian family man imagery. Country musicians may also refer to Christian ideologies and rhetoric in order to indicate a distinct attitude to music making and a related sense of manhood. They may, for instance, draw on Christian ideals of a morally responsible and mature manhood to assert themselves as country musicians and men, by condemning the 'immoral' behaviours of musicians who identify more with rock music aesthetics and male styles. This was demonstrated when a couple of men put together a touring band for going to a big interstate country music festival. The most obvious choices would have been some of the many committed country musicians in their closest Aboriginal male circles. These circles also included a guitarist firmly associated with the rock music scene, who also knew his country playing. Compared with many local musicians, he was a superior instrumentalist, had plenty of touring experience and he did not drink alcohol. It is a well-known fact that many men take the opportunity to drink seriously when away from home, creating constant problems when band members cannot be found when 
it is time to perform, or performing poorly because they are drunk or hung-over. The rock guitarist had proved over many years that he could be trusted to always turn up for a performance and do a professional job, and he was included in the tour group.

A week before they were to leave, one of the country musicians began to make displeased comments about the rock guitarist. He wanted him replaced with a man who belonged firmly in the local country music male sociality. When I asked him why, he did not question the rock guitarist's professionalism. His doubts concerned the rock guitarist's potential success among women in the Aboriginal country music scene, who, he said, were not as 'streetwise' as women in the rock scene. 'He will shame us', he argued, 'us country mob are more like family, you know. We know and respect each other!' Such family men, he implied, do not go after each other's women.

This employment of a country music family imagery of morally responsible men who protect the innocence, and in particular the sexual innocence, of their women, is particularly effective in distinguishing blackfella real country musicians as men of higher moral worth. Versions of this imagery of belonging to a morally guided community/family are often evoked by the country musicians, and it is a common explanatory frame when they describe their passion for country music. 'It is not only the music, it's a way of living and sharing together as a family', one man declared, indicating how real country is about deeper sentiments regarding how to relate genuinely to others and oneself. Such 'we're all family' imagery is strongly interlaced with Christian values emphasising male family responsibilities and monogamy. The associated models of sexually restrained family men are clearly present in the country musician's campaign against the rock guitarist who, in effect, comes to represent an anti-domesticity that relies on imagery of the rock music domain as populated by sexually predatory men and 'loose' women (e.g. Reynolds \& Press 1995).

In the setting of Aboriginal Central Australia, the power of the country music family imagery is further boosted by the all-important notion of caring for family in Aboriginal societies by maintaining effective kin relations. This includes adhering to proper gender and sexual relations according to preferred and prohibited patterns between generational and kin categories. These categories are, in turn, informed by ancestral land affiliations, and they underpin ritual relations, ceremonial practice and aspects of social relations. Indiscriminate sexual adventures (ideally) have no place in these regulated ways of conducting relations.

Here, it becomes important to distinguish between the ideal and the real. The men's ideas and moral convictions should not be confused with how they actually behave. Like other people, most of them do not live as they preach and cannot live as they desire. They live as they can with the resources and conditions that frame their day-to-day lives and upbringing in diverse settings. Their aspirations and desires may take form through identification with real country imagery, Christian values and regional Indigenous male traditions, but this does not determine their actual behaviour. As examined in more detail elsewhere (Ottosson 2006, 2009, 2010), the ways in which these men identify, and how they express blackfella and 
male forms, are intermingled and shift with social circumstances, places, the set of musicians they play with, and the kinds of events they participate in.

Ideals, ideas and convictions nevertheless have real and practical consequences for personal and musical relationships and relative male status. When the band left for the country music festival, the rock guitarist had indeed been replaced by the guitarist firmly established in the local blackfella country music sociality. Predictably, his drinking created problems during the trip. The replacement nonetheless restored some important orders of shared and competing ideas of valued masculine styles and behaviours that are mobilised, reaffirmed and negotiated in the continuous crafting of particular forms of male and musical identifications.

Country music is, of course, also about the words sung. Turning to the lyrics of real Aboriginal desert country, my focus will remain on the intercultural crafting of male social selves, not on song text analysis. I instead discuss the aspects of lyrics that the Aboriginal musicians themselves tend to emphasise in our conversations about their lyrics: the importance of having lived the story one sings.

\section{SINGING REAL LIVES}

Lyrical themes of Aboriginal desert country songs are in some aspects similar to those of global country traditions, including those of male loners expressing nostalgic and heartfelt longings for a life on the land, being down and out in a bar, suffering loneliness in jail, being on the road, regretting one's bad ways and striving to become a better man. The theme of heartbreak and love is also common, although female subjects may be both human and ancestral beings. These themes are also common in rock and reggae songs composed by Aboriginal desert musicians. In the Aboriginal version, the yearning for one's home country is often connected to belonging to one's Aboriginal kin and particular ancestral activities that are inherent in the landscape. Lyrics may describe particular desert ranges, water holes, plains or animals that are marked with specific kin-related and ancestral meanings. The respect for one's ancestral country and people is also expressed in lyrics about intercultural historical local events and injustices that have become part of particular groups' shared sense of identification. Aboriginal language words to sweet-sounding country tunes may thus describe local massacres of Aborigines that are still powerful in people's collective memories and histories.

A common theme emerging from discussions about realness with Aboriginal desert country musicians is the connection made between the lyrics, the musician and the audience. One middle-aged musician articulated this to me in a simple gesture. Moving his hand in a sweeping motion from his chest up to his mouth and towards me and my chest, he said, 'there's nothing sitting in between'. The implied free-flowing intimacy between an inner life of people and country song, unhindered by matters sitting in the way, relies on shared experience on some level, whether lived, felt or imagined. That is, real country lyrics are not only about the meaning of the words, they are about having lived and felt what is sung. 
Some older musicians connect such shared and feelingful co-existence with an experiential story-telling quality of oral traditions they were schooled in from an early age around camp fires and when moving through the bush on foot, camel or horseback with older relatives. Most of them went through stages of the ritual practices of male initiation in their teens. Referred to as 'going through Law', the initiation process included both ceremonial events and extended periods in the bush when, under the guidance of older men, they learned to hunt, find water and foods and to interpret the ancestral landscape. Herbie Laughton, acknowledged as 'the grandfather of country music in the Northern Territory' (Walker 2000:70), and who formed the first Aboriginal country band in Central Australia in the 1940s, has explained to me how 'country music is Aboriginal' by connecting it to the laborious experience of becoming a man by learning every track, tree, animal, plant and everything in the natural and ancestral landscape over many months out bush. 'These oldfellas', he told me on one occasion, 'teach you this and they sing these places. All these songs, what they sing, are real story that tells you every detail, what's happened in that country'. He connected this directly to how real country song is written and performed:

I sing any song straight out like that! Because I know them! And these mob singing and making real real country song, Hank Williams and those mob, they've had hard times. That's why their songs are real. It's experience that comes from living through all these things. That singing, it's the same with Aboriginal people. Aboriginal people always did sing about life's happening and what's happened in the land.

Herbie's own considerable book of country songs reads like a nostalgic rendition of the intercultural history of economic transformation of the Northern Territory, a place populated by hard working men, horses, cattle and camels, firmly belonging to physical and ancestral landscapes. He has told me that it was through playing, singing and writing country music that he also dealt with deep feelings of alienation and discrimination as a 'half-caste' estranged from his black kin and never feeling accepted among whites. The life experiences from which his lyrics are distilled thus become a rendition of the painful crafting of manhood for a fair-skinned boy taken away from his Aboriginal mother under racist government policies, who escaped the cruelty of the children's institution, and who spent years searching for her. All the while, he did back-breaking work for poor or no pay on cattle and sheep stations all over the Northern Territory and in South Australia. This brings us to the strong influence of the rural industries and associated manhood models in the shaping of real desert country music.

\section{REAL WORKING MEN IN COUNTRY}

Aboriginal labour was crucial for the establishment and expansion of a still important pastoral industry in Central and Northern Australia (Reynolds 2000). Up until the late 1960s, Aboriginal people worked, formed families, were born and buried at pastoral 
properties. The men (and some women) worked as horsemen, droving and branding cattle, herding and shearing sheep, digging wells and fencing, and building and maintaining homesteads for white property owners. The odd property was run or managed by Aboriginal people and this has become more common as land has been handed back to its traditional owners or purchased for them (Davis 2004). As a number of scholars have explored, the pastoral industry has thus impacted greatly, and continues to impact, on Aboriginal social worlds (Cowlishaw 1999; McGrath 1987; Merlan 1998; Rose 1991; Rose 1965; Rowse 1998 and others). Many Aboriginal men have in the process internalised masculine ideals, dress codes, manners, values and beliefs associated with this industry, as embodied by the (real and imagined) Australian stockman, the equivalent of the North American cowboy (e.g. Strang 2001).

The masculine sentiments of the pastoral industry were expressed and reinforced in country guitar music and cowboy song around camp fires at the end of the working day, as well as in all-Aboriginal domains on pastoral stations, away from nonAboriginal people. They reappeared in soundtracks to American cowboy movies, which further empowered a masculine stock worker aesthetics and a hardworking, tough sensibility Aboriginal station workers could relate to. As Davis (2005: 156) suggests in relation to Aboriginal stockmen in the north-western Kimberley region, 'film cowboys spoke to them about independence, power and vigour. Were they not also cowboys, as was John Wayne, did they not work for a boss, fight, drink, work together, chase women and drove as did their filmic companions?' And as one middle-aged Aboriginal country musician and former stock worker said to me, his reaction to seeing cowboys singing on screen for the first time was: "Jeez, I could sing about that, if only I could play like that, I'd love get into music like that!"

It may seem paradoxical that Aboriginal people have come to identify so deeply with values, practices, music and masculine ideals of a pastoral industry and frontier mentality that has caused such damage and suffering by invading Aboriginal peoples' lands, desecrating their ancestral places and degrading hunting grounds and waters. While Aboriginal people were certainly exploited as cheap or free labour, and the interdependence largely ruled by the white station owner's conditions and terms, it has been pointed out that Aborigines on cattle stations also evaded some of the close disciplining and administrative regulation that people on missions or state settlements endured (Anthony 2007). It was common practice, for instance, to allow Aboriginal workers periods in the slower work season when they could attend to ritual and family business. Former Aboriginal station men and women also frequently point out to me how they and other station people could continue to live close to their ancestral homelands, keep up ritual responsibilities and give birth to their children on this country, thus reaffirming land-body-group relations.

Stock worker skills moreover partly coincided with already existing skills and preferences among Aboriginal locals who had long lived off and with their natural and ancestral environments. For many former stockmen I have travelled with through the bush, personal identification with land seems deeply interculturally entangled as their talk about caring for cattle in harsh desert country and their 
understandings of the landscape as manifestations of ancestral beings' activities and ongoing presence become inseparable. The emotions these layered aspects of their history and manhood stir up are often powerful. More than once in my travels with such men have they stopped commenting on the country, instead grabbing a guitar from the back of the vehicle and strumming a few bars of a country tune. Or they may just sing a few lines of an old country song, in English or in their own language.

While white singing and shooting film cowboys may also seem improbable role models for exploited Aboriginal stock workers, Davis (2005) suggests that such stylish and vigorously independent screen manhood provided alternative spaces for the expression of some degree of integrity by Aboriginal men, even if it did not alleviate the invasion of land and the power of station bosses over station Aborigines. This resonates with station workers I know from Central Australia. They are certainly aware of having been exploited in the rural industry, but they tend to talk of their relationships with station owners and managers as a personal trade-off, where each party depended on the other. It was on unequal terms, but not without choices for the Aboriginal party. Information about particular stations owners and managers as 'hard men' travelled quickly in Aboriginal domains, they tell me. By 'hard' they usually mean an overtly exploitative stance informed and justified by racist typecasting of Aboriginal people that precluded meaningful relations or recognition of their experience as valuable. Owners and managers on those stations often lost good and reliable workers to white 'bosses' known to appreciate Aboriginal people's skills and knowledge of the land.

For Aboriginal people born and raised on remote stations, this was also the only life they knew: how to care for cattle, their people and the land. Real desert country music is an important expression of the often deeply held nostalgic pride people take in this working and life history. Their stories about their station past convey a certain dignity and integrity, which derives from their knowledge and presence in ancestral homelands, as well as their horsemanship and cattle skills. And just as desert country musicians lament the fact that present-day country music is taking on copy-cat American styles, former station people express sorrow over their youngfellas' lack of real experience of being skilled and in demand. They have not felt the satisfaction of hard work and the associated physical connection with ancestral country. They have not lived the lives of real country music. Yet masculine values and aesthetics of station work life remain prominent parts of the contemporary repertoire of Aboriginal models of respected manhood in the region, and both old and younger men still identify with aspects of the male models mediated in real Aboriginal country music expressions.

\section{ANALYTICAL ENDINGS}

As demonstrated by the ethnographic fragments in this article, local notions of a real quality of Aboriginal desert country music draw on aspects of male and musical 
models from different socio-economic, moral and cultural traditions. Framing this analytically in terms of intercultural mediation and recent thoughts in Aboriginal Australian studies (e.g. Myers 2002; Hinkson \& Smith 2005; Sullivan 2006), Aboriginal desert men's real country music practices constitute a process of local, national and transnational appropriations, mutual influence and transformations. In the course of an ongoing history of intercultural day-to-day social interaction and musical practice, the Aboriginal men not only reassert long established and changing ancestral models for being men and Indigenous. With every new interaction and inter-experience, aspects of these models are also co-implicated in the making of new meanings and distinctive forms of maleness, indigeneity and music. It involves the embedding of layers and layers of intercultural experiences between and within various Aboriginal lifeworlds, as well as between Aboriginal and a diverse range of non-Aboriginal expressive forms and practice. The meanings and effects of such layered experiences are interpreted in co-productive and partial ways as they are reorganised, and as they re-emerge, in different places, relations and practices.

In this way, local notions of a real quality of Aboriginal country music continue to mediate partly resonating aspects of ancestral, Christian, rural worker and other models for valued masculinity. Drawing a parallel to another adoptive expressive form in indigenous settings around the world, Turner has suggested that a consistent lesson of Kayapo video production has been how these film makers 'tend to draw upon deeply embedded cultural categories and social schemas and organizing forms for the complex visual representations they create and produce' (2002: 80). He cautions against interpreting this in terms of preservation of a fixed culture, but to understand it as 'empowerment of social actors, whatever their degree of cultural 'purity' as defined by whatever standards, to produce their own cultural mediations' (Turner 2002: 80). Such mediations, Turner suggests, are processes in which 'cultural forms, together with the capacity and motivation of social actors to produce them, are reinforced, rearticulated, and transformed in various ways through the use of new techniques of representation and new social forms of utilizing and circulating them' (2002: 80).

Similarly, a lesson of real country music making and performances in Central Australian Aboriginal settings is similarly that the male musicians draw upon a diversity of long-standing Aboriginal musical and social norms and traditions when representing themselves, always in interaction with real and imagined Aboriginal and non-Aboriginal 'Others'. In the process, they reinforce, rearticulate and transform previous and present musical and social forms for being Aboriginal and men. For these music makers, as for the video makers Turner (2000: 82) discusses, the process of music making in itself 'mediates the Indigenous categories and cultural forms that simultaneously inform and constitute its subject matter'. That is, through an important expressive form that in itself emerges from the recombination and merging of a variety of interculturally shaped practice, ideas and forms of identifications, the Aboriginal musicians craft their notions of real blackfella country and worthy manhood in contemporary desert settings. Real country is not just about 
the music, and dignified manhood is not just about being men. Such matters are also always about the inter-experience and embodiment of many possible ways of living and understanding oneself in and of the world.

\section{ACKNOWLEDGEMENTS}

The fieldwork on which the article is based was funded by Anna Ahlströms och Ellen Terselius Stiftelse, Svenska Sällskapet för Antropologi och Geografi and $\mathrm{Hu}-$ manistiska Samhällsvetenskapliga Forskningsrådet in Sweden. An early version of the article was presented at the 2008 annual meeting of the American Anthropological Association. I thank the participants for their generous comments.

Please send correspondence to Åse Ottosson: ase.ottosson@anu.edu.au

\section{NOTES}

1 The largest Aboriginal desert community, Yuendumu, has a population of $700-1000$, and most other communities have fewer than 200 residents.

2 'Blackfella' is the vernacular term used by the musicians and many other Aboriginal people when they talk about themselves and other Indigenous Australians. They use 'whitefella' for non-Indigenous people and things in general.

3 Hear these and other country and country-gospel artists on CD 1 in CAAMA's 25th anniversary compilation collection (Various Artists 2005) and hear Gus Williams and Herbie Laughton on Old Country Mates (Williams et al. 2005).

4 These events are open to anyone, but over the years I have attended, the only nonAboriginal people present have been part of Aboriginal families or belong to a small group of local country devotees who occasionally turn up.

\section{REFERENCES}

Akenson, J. E. 2003. Australia, the United States and authenticity. In P. Hayward (ed.) Outback and Urban. Australian Country Music, Vol. 1. pp. 187-206. Gympie: Australian Institute of Country Music.

Anthony, T. 2007. Criminal justice and transgression on northern Australian cattle stations. In I. Macfarlane, M. Hannah (eds.) Transgressions: Critical Australian Indigenous Histories. pp. 35-61, Canberra: ANU E Press.

Austin, T. 1992. Simply the Survival of the Fittest: Aboriginal Administration in South Australia's Northern Territory 1863-1910. Darwin: Historical Society of the Northern Territory.

Austin, T. 1997. Never Trust a Government Man: Northern Territory Aboriginal policy 1911-1939. Darwin: Northern Territory University Press.

Beal, B., R. A. Peterson 2001. Alternative country: origins, music, world-view, fans, and taste in genre formation. Popular Music and Society 25: 233-49.

Berndt, R., C. Berndt 1987. (eds.) The End of an Era: Aboriginal Labour in the Northern Territory. Canberra: Aboriginal Studies Press.

Born, G., D. Hesmondhalgh (eds.) 2000. Western Music and its Others: Difference, Representations, and Appropriation in Music. Berkeley, CA: University of California Press.

Breen, M. (ed.) 1989. Our Place, Our Music: Aboriginal Music: Australian Popular Music in Perspective. Canberra: Aboriginal Studies Press. 
Cowlishaw, G. 1999. Rednecks, Eggheads and Blackfellas: A Study of Racial Power And Intimacy in Australia. St Leonards, NSW: Allen and Unwin.

Davis, R. 2004. Aboriginal managers as blackfellas or whitefellas? Aspects of Australian Aboriginal cattle ownership in the Kimberley Anthropological Forum 14: 23-42.

Davis, R. 2005. Eight seconds: Style, performance and crisis in Aboriginal Rodeo. In D. B. Rose, R. Davis (eds.) Dislocating the Frontier: Essaying the Mystique of the Outback. pp. 145-63, Canberra: ANU E Press.

Diamond, B. 2001. Re-placing performance: a case study of the Yukon music scene in the Canadian North. Journal of Intercultural Studies 22: 211-24.

Donovan, P. 1988. Alice Springs. Its History and the People Who Made It. Alice Springs: Alice Springs Town Council.

Dunbar-Hall, P., C. Gibson 2004. Deadly Sounds, Deadly Places. Contemporary Aboriginal Music in Australia. Sydney: University of New South Wales Press.

Dusty, S., J. McKean 1996. Another Day, Another Town. Slim Dusty. Sydney: Pan Macmillan Australia.

Fitzgerald, J., P. Hayward 2003. At the confluence. Slim Dusty and Australian country music. In P. Hayward (ed.) Outback and Urban. Australian Country Music. Vol.1. pp. 29-54, Gympie, Qld: Australian Institute of Country Music.

Fox, A. 2004. Real Country: Music and Language in Working-Class Culture. Durham: Duke University Press.

Gilroy, P. 1993. The Black Atlantic. Modernity and Double Consciousness. Cambridge, MA: Harvard University Press.

Hill, B. 2002. Broken Song. T.G.H. Strehlow and Aboriginal Possession. Sydney: Knopf/Random House Australia.

Hinkson, M., B. Smith (eds.) 2005. Figuring the intercultural in Aboriginal Australia. Special issue of Oceania 75(3).

IAD 2002. Central Australian Aboriginal Languages. Current Distribution. Alice Springs: Institute for Aboriginal Development.

Jackson, M. 1998. Minima Ethnographica. Intersubjectivity and the Anthropological Project. Chicago, IL: The University of Chicago Press.

Liberman, K. 1985. Understanding Interaction in Central Australia: An Ethnomethodological Study of Australian Aboriginal People. Boston, MA: Routledge \& Kegan Paul.

McGrath, A. 1987. Born in the Cattle: Aborigines in Cattle Country. Sydney: Allen and Unwin.

Meggitt, M. 1962. Desert People. Sydney: Angus and Robertson.

Meintjes, L. 2003. Sound of Africa! Making Music Zulu in a South African Studio. Durham and London: Duke University Press.

Merlan, F. 1998. Caging the Rainbow: Places, Politics, and Aborigines in a North Australian Town. Honolulu: University of Hawai'i Press.

Myers, F. 1986. Pintupi Country, Pintupi Self. Sentiment, Place, and Politics Among Western Desert Aborigines. Berkeley, Los Angeles and London: University of California Press.

Myers, F. 2002. Painting Culture. The making of an Aboriginal High Art. Durham and London: Duke University Press.

Ottosson, A. 2006. Making Aboriginal Men and Music in Central Australia. PhD Thesis. Canberra: Australian National University.

Ottosson, A. 2009. Playing with Others and Selves: Australian Aboriginal desert musicians on tour'. The Asia Pacific Journal of Anthropology 10: 98-114.

Ottosson, A. 2010. Aboriginal music and passion: Interculturality and difference in Australian desert towns. Ethnos 73: 275-300.

Radano, R., P. V. Bohlman (eds.) 2000. Music and the Racial Imagination. Chicago, IL: The University of Chicago Press.

Reynolds, H. 2000. Black Pioneers. How Aboriginal and Islander People Helped Build Australia. Ringwood, Vic.: Penguin Books.

Reynolds, S., J. Press, 1995. The Sex Revolts. Gender, Rebellion, and Rock'n'Roll. Cambridge, MA: Harvard University Press.

Rose, F. 1965. The Winds of Change in Central Australia. The Aborigines and Angas Downs, 1962. Berlin: Akademie Verlag. 


\section{Å. Ottosson}

Rose, D. B. 1991. Hidden Histories: Black Stories from Victoria River Downs, Humbert River and Wave Hill Stations. Canberra: Aboriginal Studies Press.

Rowse, T. 1998. White Flour, White Power: From Rations to Citizenship in Central Australia. Melbourne, Vic.: Cambridge University Press.

Samuels, D. 2004. Putting a Song on Top of it. Expressions and Identity on the San Carlos Apache Reservation. Tucson, AZ: The University of Arizona Press.

Stillman, A. K. 1996. Beyond bibliography: Interpreting Hawaiian language protestant hymn imprints. Ethnomusicology 40: 469-88.

Strang, V. 2001. Of human bondage: The breaking in of stockmen in northern Australia. Oceania 72: 53-78.

Sullivan, P. (ed.) 2006. Delimiting indigenous cultures: Conceptual and spatial boundaries. Special Issue of The Australian Journal of Anthropology 17(3).

Tonkinson, R. 1974. The Jigalong Mob: Aboriginal Victors of the Desert Crusade. Menlo Park, CA: Cummings Publishing Company.

Turner, T. 2002. Representation, politics, and cultural imagination in indigenous video. In F. Ginsburg, L. Abu-Lughod, B. Larkin (eds.) Media Worlds. Anthropology on New Terrain. pp. 75-89, Berkeley, Los Angeles, London: University of California Press.

Various artists 2005. CAAMA 25 Years Anniversary Compilation. CD 1. Alice Springs: CAAMA Music.

Wade, P. 2000. Music Race and Nation: Musica Tropical in Colombia. Chicago: The University of Chicago Press.

Walker, C. 2000. Buried Country. The Story of Aboriginal Country Music. Annandale: Pluto Press.

Whiteoak, J. 2003. The frontiers: early cowboy music in Australian popular music. In P. Hayward (ed.) Outback and Urban. Australian Country Music, Vol. 1. pp. 1-89. Gympie, Qld: Australian Institute of Country Music.

Williams, G., H. Laughton, B. Randall 2005. Old country Mates. Alice Springs: CAAMA Music. 